\title{
Visual Representations of Indigenous Cultures in Norwegian EFL Textbooks
}

\author{
Cecilie Waallann Brown \\ University of Stavanger \\ Jena Habegger-Conti \\ University of Stavanger
}

\begin{abstract}
This article presents a summary of research conducted on the visual representation of indigenous cultures in four English textbooks produced for Norwegian lower secondary schools with the aim of investigating the extent to which images of indigenous people contribute to, or contradict, the general cultural aims of the English language learning curriculum in Norway. Over 800 textbook images were analyzed using the methods of visual content analysis and semiotic image analysis. A qualitative analysis of two photomontages also provides a more holistic approach to the study and helps to more clearly explain the quantitative results. The results from the research show a strong trend to focus on traditional aspects of indigenous people, a tendency to represent indigenous people in a lower position of power than the viewer, and to distance the viewer. Comparatively, the images of white people more frequently invite the viewer to interact and empathize with the participants.

Consequently, the research concludes that the images in the four EFL textbooks analyzed are, to a large degree, potential carriers of ideologies in direct contradiction of the general cultural aims of English language learning in Norway. The implications of these findings are that images and how they position readers should a part of EFL teaching.
\end{abstract}

\section{Introduction and aims}

Textbook images provide an immediate window into what another culture is like, and may thus help students to achieve the aim of intercultural competence in the foreign language classroom. However, as will be shown, textbook images of other cultures may contribute to and reinforce stereotypes rather than challenge discriminatory beliefs.

This article presents a summary of some of the findings of a recent study by the first author on the visual representation of indigenous cultures in four English as a Foreign Language (EFL) textbooks produced for Norwegian lower secondary schools. ${ }^{1}$ Over 800 textbook images were analyzed in the study using the methods of visual content analysis and

\footnotetext{
${ }^{1}$ All of the results from this extensive analysis, including statistics categorized by textbook are available at: http://hdl.handle.net/11250/2400302.
} 
semiotic image analysis to determine to what extent images of indigenous people in EFL textbooks for lower secondary schools contribute to or contradict the general cultural aims of English language learning in the Norwegian LK06 curriculum. A qualitative analysis of two photomontages also serves to provide a more holistic approach to the effect that individual pictures can have on the viewer, and helps to more clearly explain the quantitative results. Of particular importance to the study was what type of power relationships and reader identification the images demanded, and whether or not the images could be said to strengthen intercultural competence and democratic citizenship, competences promoted for education in Norway and Europe, or whether they reinforced cultural stereotypes and an "us" and "them" mentality.

The findings of the study also raise awareness about the need for the development of visual literacy skills amongst teachers and pupils, especially to meet the English subject competence aims related to intercultural competence. The methods of analysis used in the study may aid teachers and students in a critical visual literacy approach to meet these curriculum aims.

\section{Background to the study}

\section{1. Intercultural competence in language learning}

Over the past thirty years intercultural competence has been primarily understood in a European context as a language issue that can be resolved through a functional approach: the appropriateness of certain behaviors and the ability to act in accordance with the conventions particular to the foreign community (COE 2001: 104), the ability to deal with intercultural misunderstandings and conflict situations, and the ability to overcome stereotypes (Byram 2012). In recent years theorists such as Claire Kramsch and Adrian Holliday have criticized previous research into intercultural competence as essentialist and reductive (Kramsch 2002; Holliday et al 2010) and put forward the notion of critical intercultural competence, to focus more on values and ideologies. Bøhn and Dypedahl have argued that attitudes such as curiosity, openness, and tolerance should form an essential part of intercultural competence (2009: 154) and they seek to problematize the practice of teaching cultures in terms of "us" and "them".

Several recent documents, both in Norway and in Europe, emphasize the importance of intercultural competence to both education in general, and to the teaching of English. According to the Purpose section of the English subject curriculum in Norway:

Development of ... cultural insight can promote greater interaction, understanding and respect between persons with different cultural backgrounds ... and cultural competence promote(s) the general education perspective and strengthen(s) democratic involvement and co-citizenship. (UDIR 2013: 2).

Additionally, the main subject area "Culture, Society and Literature" stresses that working with a variety of texts is essential to "develop knowledge about, understanding of and respect for the lives and cultures of other people" (UDIR 2013: 3).

These aims are also highlighted in the recent document Fremtidens Skole: Fornyelse av fag og kompetanser (The School of the Future: Renewal of Disciplines and Competencies), published in August 2015: "A central goal for student learning must be that they are able to interact in a variety of social arenas, not least those related to democratic participation, 
tolerance, and social responsibility" (UDIR 2015: 10). The key words and themes from these documents echo current educational policies in Europe. For example, the Council of Europe's White Paper on Intercultural Dialogue (COE 2008), titled "Living Together as Equals in Dignity", emphasizes dialogue as a key component of interculturalism and as a solution for dealing with difference in an increasingly globalized world. It further highlights the importance of an intercultural education to foster global citizenship and respect for differing lifestyles.

Despite the broad and united push for intercultural competence, however, the English subject curriculum in Norway remains extremely vague regarding what type of intercultural competence students are expected to achieve, relying heavily on the repeated and not welldefined verb: "å drøfte ..." (to discuss). As an example, by the end of tenth grade, students should be able to "discuss living and socializing in Great Britain, the USA, and other Englishspeaking countries and Norway". Achieving this aim could presumably mean being able to speak about anything from the type of sports teenagers like to play in each country, to more serious political or economic issues related to lifestyle.

The English subject curriculum does not addresses the notion of stereotypes or mention concepts like "otherization" and essentialism, and in fact seems to encourage them with competence aims from the fourth to tenth grade asking students to compare "Englishspeaking cultures" with "Norwegian culture" for the purpose of reflecting on one's own culture, attitudes and beliefs. The problem with goals such as this is not in reflection, but in the culturally-constructed ways that people are taught to imagine the Self as "normal" or "superior" and the Other as "alien". Holliday explains:

By otherization we mean imagining someone as alien and different to 'us' in such a way that 'they' are excluded from 'our' 'normal,' 'superior' and 'civilized' group. Indeed it is by imagining a foreign Other in this way that 'our' group can become more confident and exclusive' (Holliday 2004: 3).

Reflection thus becomes a reinforcement of the beliefs and attitudes already held.

Kramsch argues that practitioners and theorists of intercultural communication must confront inequalities and conflicts in cultures and not ignore who has access to discourse and power and who does not. For Kramsch this means that language teachers should "focus less on seemingly fixed, stable cultural entities and identities on both sides of national borders" (1995: 8). She further advocates that foreign languages be taught as an "oppositional practice". defined by her as "critical cross-cultural literacy".

\subsection{Images as carriers of culture}

It has been argued that part of the educational process is socialization into the attitudes, beliefs and values of one's own culture (cf. Freire 1970; Althusser 1971; Jackson 1968; Giroux 1983), one of the difficulties in teaching culture and / or interculturalism is not how we get to know, understand and respect others, but how well we know ourselves. Research in the area of visual literacy argues that interpretation depends upon the imageproducer and the reader engaging in a culturally- and socially-bound agreement (Hall 1972; Cohn 2013; Eisner 2008). Thus when reading images, learners are more apt to read into them from their own belief systems, rather than to meet those represented in the images for the first time, with no prior schema (Berger 1972; Cohn 2013). 
Images communicate their message best through what appears as commonsense, what is taken for granted in a culture (Hall 1997). Thus visual texts, even more so than written texts, are more or less always communicating within agreed-upon social conventions about what looks nice, scary, interesting, etc. Images that are intended to represent reality thus must be made to appear natural, as though there is nothing to resist or contest.

Historically, the photograph has been considered as a relatively objective representation, compared to that of painting or drawing (Sturken \& Cartwright 2009: 16-17). In her seminal study explaining the role of photography in furnishing evidence, Susan Sontag explains that photographs, unlike other mimetic objects such as paintings, are perceived to be nearer reality than other types of images (Sontag 1977: 5). They furnish evidence, and can work to prove the existence of something previously doubted. However, at even a basic level, it is indisputable that choices must be made when taking a photograph: choices in regard to composition, angle, lighting, positioning of the elements, etc.

Hilary Janks points out that no text is neutral and always reflects the choices of the text-producer. "Texts have social effects ... they are designed to recruit us into their version of 'the truth"' (Janks, Dixon, Ferreia, Granville \& Newfield 2014: 1). The problem, however, is that people's awareness of the subjectivity of the photograph is largely subdued (Sturken \& Cartwright 2009: 18) and therefore much of the authority of the photograph originates from the fact that it is perceived as an objective copy of reality, and thus neutral.

\section{Research on textbook images and cultural stereotyping}

It is now generally accepted in the field of visual studies that images, rather than being viewed simply as illustrations of a verbal text, carry their own meaning and can, in and of themselves, be "read". Visual literacy has been defined at a basic level as the "ability to construct meaning from visual images" (Giorgis et al, 1999: 146), and more in-depth as a "set of skills needed to be able to interpret the content of visual images, examine social impact of those images and to discuss purpose, audience and ownership" (Bamford 2003).

However, research into how images are taught and read in the classroom is still a relatively new field. Arizpe and Styles (2004) found that reading images "makes demands on what are often called 'higher order reading skills' (inference, viewpoint, style and so on) and involves deep thinking" (195). Howells and Negreiros argue that while most students learn to recognize elements of content, style and structure in a written text, the majority remain "visually illiterate", reading images only at a surface level of determining what is happening in the image (2012: 5). A survey of visual literacy skills amongst fifth graders in the U.S. showed that while both pupils and their teachers were good at reading the individual signs of ads, both groups performed poorly when it came to identifying the underlying ideologies conveyed by the ads (Albers et al 2008, ctd. in Vasquez 2013: 10).

Only a handful of studies have focused on ideology and images in EFL textbooks: Lee's (2014) research into gender representation in Japanese EFL textbooks revealed a bias against women; Marefat and Marzban's (2014) multimodal analysis of gender representation in Iranian textbooks for teaching English indicated that while men were depicted in a more visible and active way, the women were both invisible and underrepresented; Giaschi's (2000) critical image analysis of ESL texts made by the British Council showed that the 
images communicated a strong gender positioning. Giaschi also argued that the British culture communicated was predominantly patriarchal and capitalistic.

Of particular interest to teaching culture in the EFL classroom is a study by TaylorMendes (2009) that focused on responses by students and teachers images in EFL textbooks in relation to race, class or gender. Taylor-Mendes found that many of the textbooks in use in Brazil work to enforce already established stereotypes of the "white American" as powerful and that "EFL images do not so much represent culture as construct cultural and racial identities" (2009: 77). For Taylor-Mendes the "most worrisome" findings were that the textbook images reinforce the stereotypes and racial biases that students already held, rather than challenging the students with a new way of viewing people (2009: 76).

In Norway two studies shed some light on the problems textbook images present to developing intercultural competence. An extensive study of primarily written texts in EFL textbooks used in Norway under the L97 curriculum by Ragnhild Lund concluded that "many cultural groups are presented in one text only, and the pictures that are provided are sometimes fragmentary, one-sided and superficial" (Lund 2006: 281). Furthermore, the study showed that on the whole, the textbooks used in Norway did not encourage intercultural learning (Lund 2006: 290), but instead provided many examples of stereotypical representations of cultures, for example by representing Hispanics "... only as people who try to cross the Mexican border illegally" (2006: 281). ${ }^{2}$ The findings also showed a tendency towards exoticisation (2006: 282).

More recently, Geir Winje found that religion textbooks in Norway treat religious art that is part of a western canon differently than non-western religious art. Images by western artists were understood as critical and original and belonging to historical epochs, while images by non-western artists were anonymous and repeated the same pre-modern motifs. Winje found that the non-western images could be interpreted as "exotic" and "inaccessible" (Winje 2014: 15).

\section{Materials and Methods}

The data collection for the present study included all visual representations of indigenous people ${ }^{3}$ and "white" people 4 from four different EFL textbook collections made for the three years of lower secondary school in Norway (thus twelve books in total): Crossroads, Key

\footnotetext{
${ }^{3}$ Since indigenous people are not defined by their biological features but by their cultural identity, the selection of images relied on cultural references within the image, such as clothing or artifacts, or explicit reference in the surrounding text.

${ }^{4}$ The authors of the article wish to make clear their belief that whiteness does not exist as a true biological category, but is rather a "race" attributed to people displaying a lack of other racial qualities (cf. Dyer 1997). Thus, "white" has come to represent the "norm" and "nonwhite" as "other". For the purpose of this analysis, participants were categorized as white when their outward appearance conformed to the dominant cultural agreements regarding whiteness as a light skin color.
} 
English, New Flight and Searching. The textbooks were chosen because they are currently in use in Stavanger area schools, and because they represent four different major publishing companies. The analysis was limited to indigenous cultures for two main reasons: it was within the first author's own experience, both as a student and as a teacher, that indigenous people are frequently represented as traditional and "Other" in the educational context in Norway. Secondly, because indigenous peoples are explicitly mentioned in one of the competence aims in the English curriculum in Norway, it could be expected that visual representations of them would be found in all textbook series.

The main methods used in the study were visual content analysis and semiotic image analysis, quantitative methods used to classify and count certain types of occurrences for the purpose of making generalizations. A brief overview of these methods will be given below. Finally, a qualitative analysis of two photomontages also serves to provide a more holistic approach to the effect that individual pictures can have on the viewer, and helps to more clearly explain the quantitative results.

For the content analysis information was gathered regarding the who and what of the image for the purpose of answering the research question: "To what extent do the images that are presented as representing indigenous cultures reinforce cultural stereotyping?" Images were classified according by setting (modern, traditional ${ }^{5}$ and neutral), and by the type of clothing worn by those pictured (modern or traditional).

The second part of the study looked at how the represented participants in the images were depicted to determine whether any systematic differences occurred in how the viewer is positioned in relation to people from indigenous cultures compared to white people in relation to power and identity.

According to Janks (2010: 61), "all texts are positioned and positioning". Positioning involves both the text-producer and the viewer and refers to their beliefs, values and attitudes, social positions (race, class, age, etc.), geographical location, and life experiences such as education, languages spoken or travel.

Following Jewitt \& Oyama (2001) and Kress and van Leeuwen (2006), in order to reveal an image's positioning, a structural analysis may be used, which includes reading eye contact between the participant represented in the image and the viewer. In visual studies this is widely referred to as "the gaze", "spectatorship" or "the act of looking". Theorists of visual literacy suggest that a fundamental difference exists between images where the represented participant is looking directly at the viewer and not. When a represented participant is depicted looking out of the image, he or she "...interpellates the human subject who looks at it with a look back - that is, a call, an appeal, or an address (Sturken \& Cartwright 2009: 104). Kress and van Leeuwen term this address as "demand" - participants demand for a relationship (albeit imaginary) to be formed (Kress \& van Leeuwen 2006: 118). In contrast, images which contain participants that do not look out at the viewer are classified as "offer", which means that the participant offers himself or herself to be viewed, seemingly unaware. Here the viewer is positioned as a voyeur, free to look at the participant without being caught

\footnotetext{
${ }^{5}$ Applying a dichotomy like this is not unproblematic, as it raises questions about what is considered "traditional" and "modern", and who has the power to decide. At the same time, the dominant cultural understandings of these terms also affects the way that teachers and students may interpret these images.
} 
in the act of looking. The viewer is conventionally awarded more power than the person who is viewed.

An analysis of the gaze can also be used to determine the level of engagement that viewers are positioned to have with participants. For example, Kress \& van Leeuwen (2006: 119) found that in an Australian primary-school textbook, the Aboriginal participants rarely looked directly at the viewer and are thus depicted as objects of contemplation, not as subjects for the pupil to enter into an imaginary social relationship with" (Kress \& van Leeuwen 2006: 120).

The angle from which the viewer sees the participant can also be used as a determiner of power. If the represented participant is depicted from a high angle, it typically indicates that he or she is of a lower status than the viewer (Kress \& van Leeuwen 2006: 140): the viewer is positioned to "look down" on the participant. In contrast, if the participant is shown from a low angle, with the viewer looking up at the participant, the viewer is positioned to admire and give power to the participant. If the participant is depicted at eye-level with the viewer, the power relationship implied between the participant and the viewer is neutral, or equal. Horizontal angles also play a role in determining the imaginary social relationship created between viewer and participant: Frontal angles increase involvement, while oblique angles enforce detachment (Kress \& van Leeuwen 2006: 136).

The choice of frame can also suggest a close or distant relationship between the represented participants and the viewers (Kress \& van Leeuwen 2006: 124). A close shot implies intimacy, whereas the long shot is more impersonal.

In addition to the quantitative analysis outlined above, a qualitative analysis using critical visual literacy as well as elements from semiotic image analysis, was applied to a selection of the images, mainly to provide a more holistic approach to the effect that individual pictures can have on the viewer. Additionally, it helps to more clearly explain the quantitative results. As such, the selection of the images for this part of the analysis was neither random nor widespread. Instead, the images were selected based on either being particularly useful in relation to providing nuances to the discussion, or particularly interesting in its effect on the viewer.

Janks et al. (2014: 85) propose a sequence of three steps as a method of reading images critically, covering the three areas what/who, how and where. In the first step, the reader is suggested to look at the visual content of the image. Here, questions such as who or what the image depicts, and does not depict are central. In the second step, the focus shifts to how the depicted people or items are represented. The angle, lighting and colors are all important factors towards how the image is interpreted. In the final step, Janks suggest looking at the image in its context, analyzing the textual, social and political context of which the image appears.

The contextual elements of the images were addressed in this analysis both through looking at the individual elements of the multimodal text, as well as the layout of the text as a whole. Because this study was mainly concerned with visual representations, no in-depth analysis was conducted on the verbal text. However, the verbal texts were read with the aim of analyzing how it potentially influenced the visual message. The tasks connected to the context of which the images are found were also analyzed, in order to see if any of the tasks involved the use of the images, and if so what effect that might have on the reader's interpretation. These three steps were all to some degree covered in the qualitative analysis, the extent of which decided by the nature of the image in 
question. Because of its qualitative nature, the results from this part of the study will be presented in narrative form, while the images in question are included in the appendices.

\section{Findings and Discussion \\ 5.1. Quantitative results}

The results of the content analysis show that just over $50 \%$ of the images representing indigenous cultures show people in a traditional setting with no elements of the modern world present (see Table 1.), and over $60 \%$ of the indigenous participants in the images are depicted wearing traditional clothing.. In New Flight, this frequency was as high as $90 \%$ (see Table 2.). Furthermore, all of the four textbook collections in the study depicted participants from at least one indigenous culture exclusively in traditional clothing. The argument here is not that representing Indigenous peoples' cultural heritage is undesirable, in the same way that it would not be undesirable to represent a Norwegian wearing a "bunad" (Norwegian national costume) or performing "hallingdans" (traditional Norwegian folk dance).

Through repeated representations of indigenous people in their traditional clothing and settings, the textbooks run the risk of reinforcing the stereotype of indigenous people as traditional, primitive, and unable to assimilate with the modern world. This coincides with Lund's (2006) findings that in many cases textbooks focus on the most exotic characteristics of a foreign culture. One possible consequence of this stereotyping is that the images position the viewer to see indigenous people as static, and it further encourages an essentialist view of culture. Additionally, indigenous people, unlike whites, often go unnamed in these images and serve as representatives of an entire culture, way of life, or particular concept that students are learning.

Table 1.

Categorization of setting in the Indigenous corpus

\begin{tabular}{llll}
\hline & Traditional & Modern & Neutral \\
\hline Crossroads & $10(43.5 \%)$ & $9(39.1 \%)$ & $4(17.4 \%)$ \\
Key English & $7(31.8 \%)$ & $7(31.8 \%)$ & $8(36.4 \%)$ \\
New Flight & $18(75 \%)$ & $3(12.5 \%)$ & $3(12.5 \%)$ \\
Searching & $13(54.2 \%)$ & $3(12.5 \%)$ & $8(33.3 \%)$ \\
Total & $48(51.6 \%)$ & $22(23.7 \%)$ & $23(24.7 \%)$ \\
\hline
\end{tabular}

Table 2.

Categorization of indigenous participants' clothing

\begin{tabular}{lll}
\hline & Traditional & Modern \\
\hline Crossroads & $24(66.7 \%)$ & $12(33.3 \%)$ \\
Key English & $22(44 \%)$ & $28(56 \%)$ \\
New Flight & $26(89.7 \%)$ & $3(10.3 \%)$ \\
Searching & $27(62.8 \%)$ & $16(37.2 \%)$ \\
Total & $99(62.7 \%)$ & $59(37.3 \%)$ \\
\hline
\end{tabular}


Using a visual semiotic analysis of photographic techniques such as the angle of shots (bird's eye, high, eye-level, low, oblique), position of the gaze (demand or offer), and frame (wide, close-up, etc.) sought to investigate power relationships in the photos. This portion of the study found that viewers of the textbook images are positioned more frequently to identify or interact with white participants than they are with indigenous participants, thus increasing the "us vs. them" divide. This is due both to lack of eye contact between the indigenous participant and the viewer (the viewer is invited to gaze at the participant, but the participant does not look at the viewer) and to the distance, or sense of detachment, created by impersonal (wide) framing. Although close and medium shots are nearly the same for images of whites and indigenous people (but still occur less frequently with indigenous people), nearly $40 \%$ of indigenous participants in the textbooks are depicted from an impersonal angle, compared to only $18 \%$ of white participants (see Table 3.).

Table 3.

Categorization of social distance, as defined by the frame

\begin{tabular}{lllllll}
\hline & $\begin{array}{l}\text { Intimate } \\
\text { (Close) }\end{array}$ & & $\begin{array}{l}\text { Social } \\
\text { (Medium) }\end{array}$ & & $\begin{array}{l}\text { Impersonal } \\
\text { (Wide) }\end{array}$ \\
& $I P$ & $W P$ & $I P$ & $W P$ & $I P$ & $W P$ \\
Crossroads & 6 & 69 & 16 & 203 & 14 & 80 \\
& $(16.7 \%)$ & $(19.6 \%)$ & $(44.4 \%)$ & $(57.7 \%)$ & $(38.9 \%)$ & $(22.7 \%)$ \\
Key English & 7 & 63 & 18 & 306 & 25 & 108 \\
& $(14.3 \%)$ & $(13.2 \%)$ & $(36.7 \%)$ & $(64.2 \%)$ & $(51 \%)$ & $(22.6 \%)$ \\
New Flight & 4 & 74 & 18 & 428 & 7 & 62 \\
& $(13.8 \%)$ & $(13.1 \%)$ & $(62.1 \%)$ & $(75.9 \%)$ & $(24.1 \%)$ & $(11 \%)$ \\
Searching & 3 & 80 & 28 & 258 & 12 & 77 \\
& $(7 \%)$ & $(19.3 \%)$ & $(65.1 \%)$ & $(62.2 \%)$ & $(27.9 \%)$ & $(18.6 \%)$ \\
Totals & 20 & 286 & 80 & 1195 & 58 & 327 \\
& $(12.7 \%)$ & $(15.8 \%)$ & $(50.6 \%)$ & $(66.1 \%)$ & $(36.7 \%)$ & $(18.1 \%)$ \\
\hline
\end{tabular}

$\mathrm{IP}=$ indigenous participants $\mathrm{WP}=$ white participants

In terms of whether power is awared to the participant or the viewer, people from indigenous communities are also depicted twice as often from a high vertical angle than people who can be defined as "white" (see Table 4.). This angle causes them to more often appear "small and insignificant" to the reader, while whites more often appear "imposing and awesome" (Kress and van Leeuwen 2006: 146). 
Table 4.

Categorization of power relationship, as defined by the vertical angle

\begin{tabular}{lllllll}
\hline & $\begin{array}{l}\text { Viewer power } \\
\text { (High angle) }\end{array}$ & $\begin{array}{l}\text { Equality } \\
\text { (Eye-level) }\end{array}$ & \multicolumn{2}{l}{$\begin{array}{l}\text { Participant power } \\
\text { (Low angle) }\end{array}$} \\
\hline \multirow{2}{*}{ Crossroads } & $I P$ & $W P$ & $I P$ & $W P$ & $I P$ & $W P$ \\
& 0 & 58 & 35 & 272 & 1 & 22 \\
Key English & $(0 \%)$ & $(16.5 \%)$ & $(97.2 \%)$ & $(77.3 \%)$ & $(2.8 \%)$ & $(6.3 \%)$ \\
& $(32.7 \%)$ & $(10.5 \%)$ & $(65.3 \%)$ & $(80.3 \%)$ & $(4.1 \%)$ & $(9.2 \%)$ \\
New Flight & 3 & 48 & 20 & 468 & 6 & 48 \\
& $(10.3 \%)$ & $(8.5 \%)$ & $(69 \%)$ & $(83 \%)$ & $(20.7 \%)$ & $(8.5 \%)$ \\
Searching & 14 & 32 & 28 & 338 & 1 & 45 \\
& $(32.6 \%)$ & $(7.7 \%)$ & $(65.1 \%)$ & $(81.4 \%)$ & $(2.3 \%)$ & $(10.8 \%)$ \\
Totals & 33 & 188 & 115 & 1461 & 10 & 159 \\
& $(20.9 \%)$ & $(10.4 \%)$ & $(72.8 \%)$ & $(80.8 \%)$ & $(6.3 \%)$ & $(8.8 \%)$ \\
\hline
\end{tabular}

$\mathrm{IP}=$ indigenous participants $\mathrm{WP}=$ white participants

The results also show a significant difference in eye contact between the participants in the image and the image viewer. On the whole, the reader is roughly twice as likely to make eye contact with white people than with indigenous people (see Table 5.). In some instances, eye contact is nearly three times as likely, such as in Key English, where eye contact is established with indigenous people in only $10 \%$ of the pictures representing them. Lack of eye contact creates an uneven power relationship between the reader and person depicted. Although the relationship is imagined, it nevertheless prevents the reader from engaging in a social relationship with the image, or empathizing with the people depicted. 


\section{Nordic Journal of Modern Language Methodology}

Table 5.

Categorization of the gaze, as defined by eye-contact

\section{Demand}

(Eye-contact)

\section{Offer}

(Lack of eye-contact)

\begin{tabular}{lllll}
\hline & $I P$ & $W P$ & $I P$ & $W P$ \\
Crossroads & 5 & 100 & 31 & 252 \\
& $(13.9 \%)$ & $(28.4 \%)$ & $(86.1 \%)$ & $(71.6 \%)$
\end{tabular}

$\begin{array}{lllll}\text { Key English } & 5 & 135 & 45 & 342 \\ & (10 \%) & (28.3 \%) & (90 \%) & (71.7 \%) \\ \text { New Flight } & 6 & 133 & 23 & 431 \\ & (20.7 \%) & (23.6 \%) & (79.3 \%) & (76.4 \%)\end{array}$

\begin{tabular}{lllll} 
Searching & 7 & 115 & 36 & 300 \\
& $(16.3 \%)$ & $(27.7 \%)$ & $(83.7 \%)$ & $(72.3 \%)$ \\
Totals & 23 & 483 & 135 & 1325 \\
& $(14.6 \%)$ & $(26.7 \%)$ & $(85.4 \%)$ & $(73.3 \%)$ \\
\hline
\end{tabular}

$\mathrm{IP}=$ indigenous participants $\mathrm{WP}=$ white participants

Another problem highlighted by the study is the grouping and confining of images of indigenous peoples into one textbook chapter or unit, which reinforces the marking of these peoples as "Other", and as not integrated into the rest of the society.

As will be shown through a brief qualitative analysis of two photomontages, when used to compare cultures, often create "us" / "them" dichotomies between "whites" who are shown as active, complex and technologically advanced, and indigenous peoples who appear passive, primitive and simple.

\section{1 Qualitative analysis of photomontages}

\section{Photomontage depicting 'Native people'}

Figure 1 below shows a two-page photomontage at the start of the chapter "Native people" in New Flight 2. It consists of a front page containing a title and a large image, followed by smaller images that are related to the topic addressed: Inuit, Native Americans, Aboriginals and Maoris. Each indigenous culture is represented in two images, amounting to eight images in total. 
Figure 1.

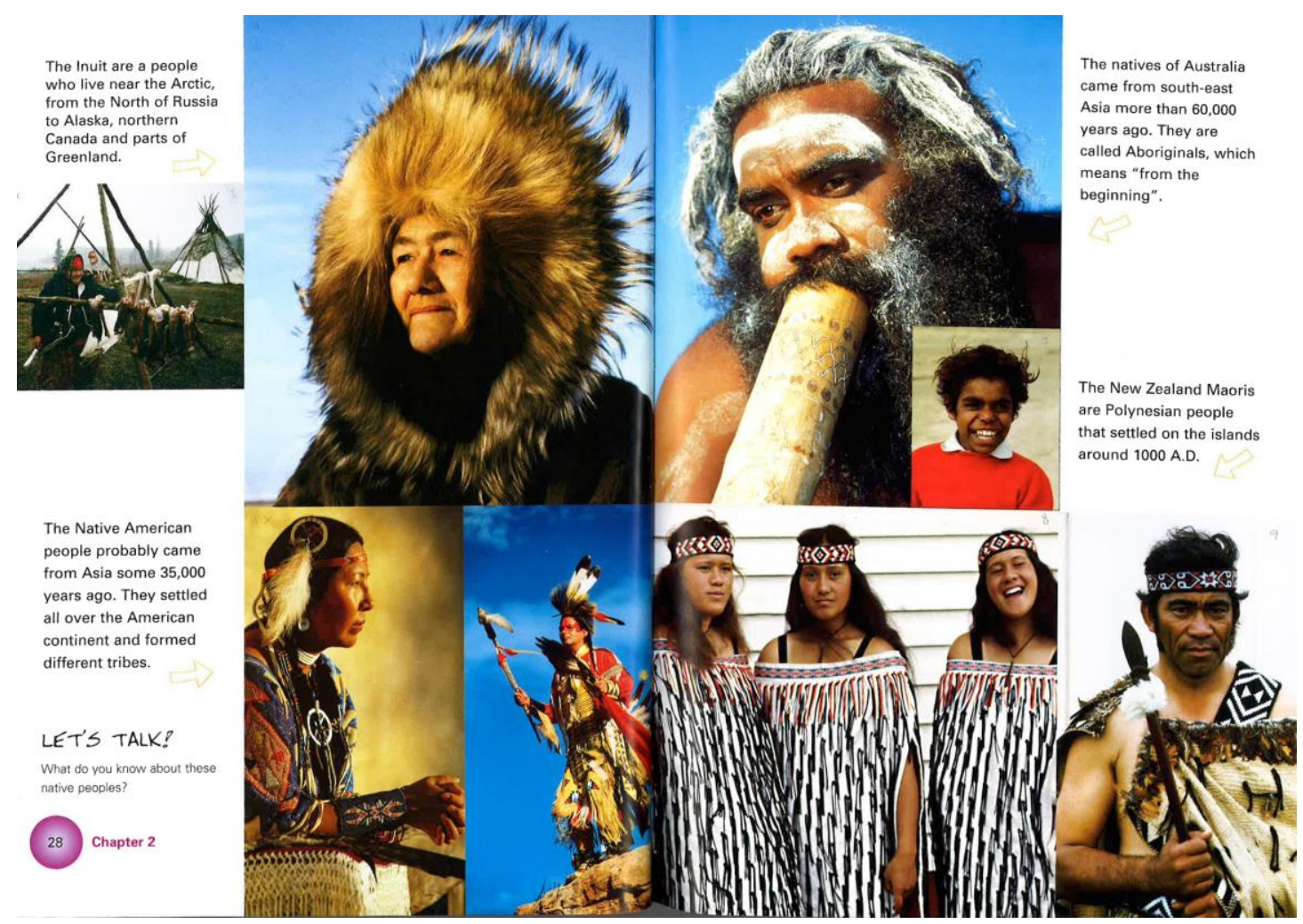

New Flight 2, 2007: 28-29

Only one of these images can be categorized as exclusively modern. This is the image of an Aboriginal boy wearing a white shirt underneath a red jumper. The boy is smiling and looking at something or someone who appears to be just to the right of the viewer. As such, the boy is not looking directly at the viewer and therefore the viewer cannot engage with him. This is consistent with the other indigenous participants in the photomontage, of which only two make eye-contact with the viewer.

Short texts accompany the images, providing generic information about the different indigenous peoples, mainly focusing on historical facts such as "The Native American people probably came from Asia some 35,000 years ago. They settled all over the American continent and formed different tribes" (New Flight 2 2007: 28). No specific information about the people depicted in the images is given. A task is also included on the two-page layout, asking the question: "What do you know about these native peoples?" (New Flight 2: 28). There is no explicit reference to the images in the task.

Although the task does not explicitly ask the pupils to use the images as a prompt to retrieve their knowledge, this might be inferred from the context as the task is surrounded by images. While the images potentially change the meaning of the text, the text also has the potential to change the meaning of the images, by pointing the pupils towards what 
'knowledge' is in this context. Furthermore, the task, as well as the placement of the photomontage at the beginning of the chapter, encourages the use of the layout as a general introduction to the topic. Consequently, the pupils are from the very start positioned to view indigenous people as belonging in the past.

Finally, it can be pointed out that out of ten participants in this two-page layout, only two of the participants in the images are actively doing something. The rest are passive, posing for the images in their traditional outfits. When comparing these images to those of the two-page photomontage in the preceding chapter, "When School's Out" (see Figure 2.) the contrast is striking. The participants in this photomontage are active, reading, cycling or playing videogames, etc. Moreover, this photomontage mainly depicts young teenagers, whereas the majority of the participants in the indigenous photomontage are of an adult age. Consequently, pupils in lower secondary are positioned by the images to relate more naturally to those people who appear to be like them: young teenagers in western society.

Figure 2.

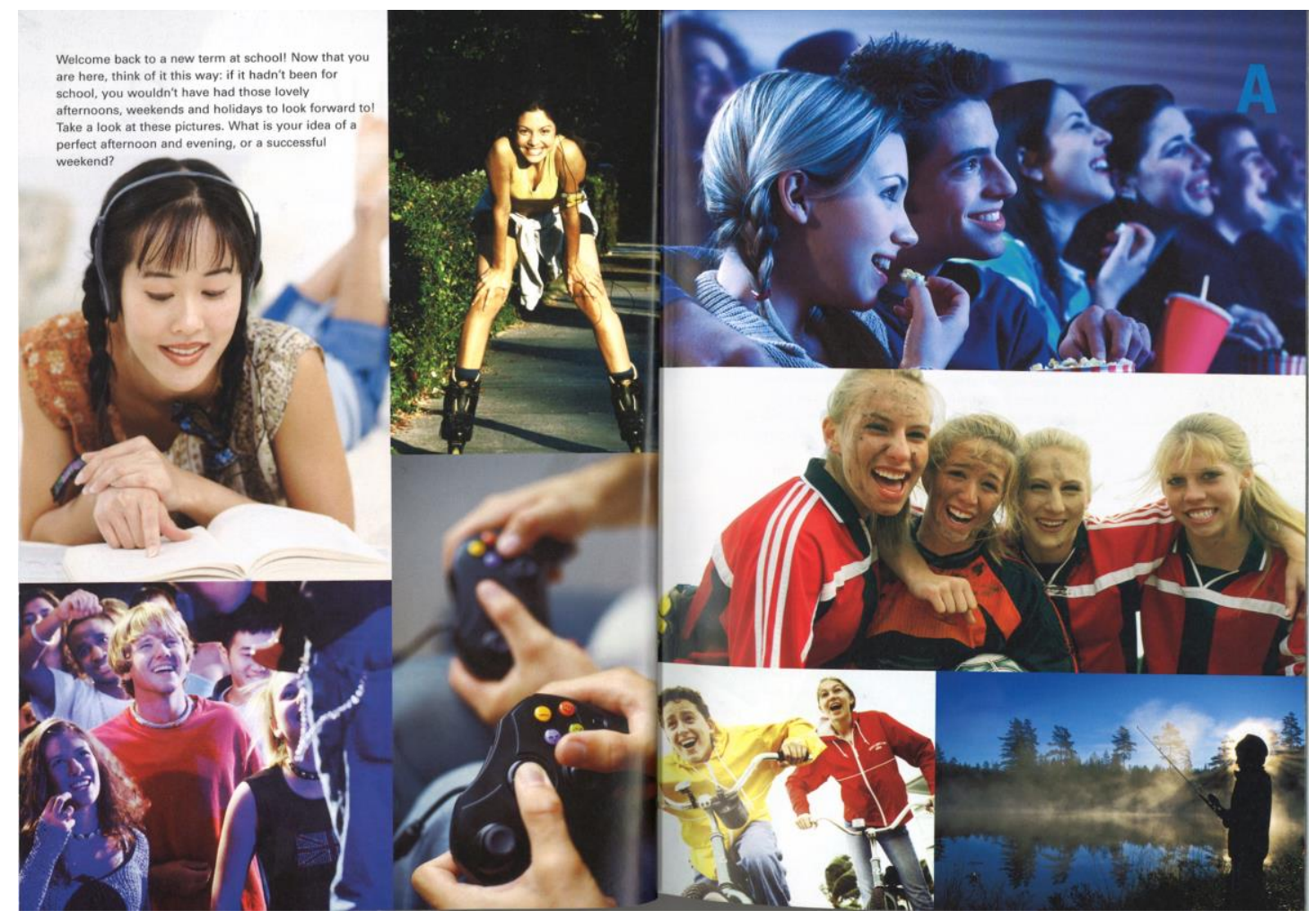

New Flight 2, 2007: 8-9

\section{Photomontage depicting 'Australia'}

Another photomontage in New Flight that depicts indigenous cultures can be found at the start of a chapter named "Down under" in New Flight 1, which is about Australia and New Zealand. The photomontage consists of six images, two of which will be discussed here (see Figure 3.). The two images are placed on the bottom left side of the two-page layout. Placed 
to the left is an image depicting a white, Australian, girl communicating with her teacher using a radio transmitter. To the right of this, the other image can be found, depicting an Aboriginal boy having his face painted. A short description of the image states the following: "The natives of Australia are called Aborigines. They often paint their faces and bodies before performing a ritual dance" (New Flight 1: 155).

\section{Figure 3.}

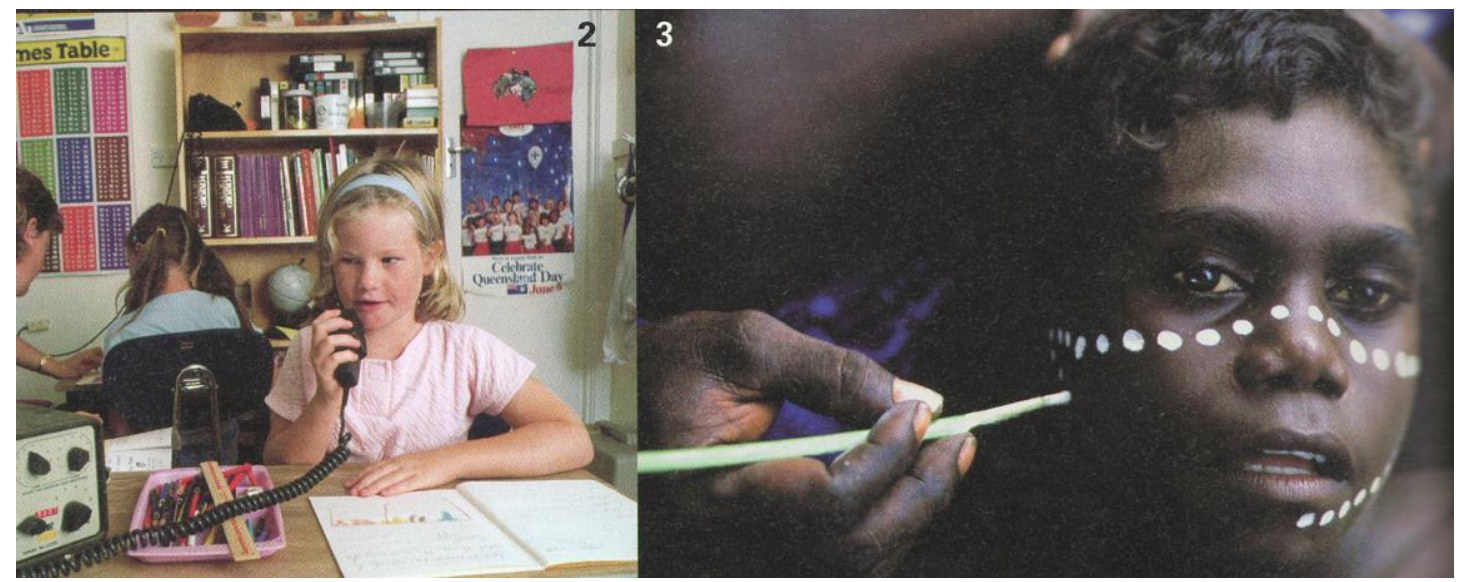

New Flight 1, 2006: 154

There are several differences between the two images. Firstly, the girl is presented in an active role, using a radio, while the boy is presented in a passive role, getting his face painted. Secondly, the image of the girl contains light colors, whereas the image of the boy is almost solely comprised of dark colors, with the facial painting as well as the tool used for painting constituting the most salient elements of the image. Furthermore, the framing of each image is different. The girl is depicted in a medium, or social, frame, which includes more of the surroundings. In contrast, the boy is depicted in a very close, or intimate, frame and the only context which is visible is a hand holding a tool used for painting.

Whereas the "white" Australian is depicted in a modern school environment, which the pupils would relate to, the Aboriginal Australian is presented as belonging to a people who "...often paint their faces and bodies before performing a ritual dance" (New Flight 1: 155). The extreme difference in color between the two images further increases the difference between the two images. Instead of decreasing the stereotype of indigenous people as traditional and primitive, the juxtaposing of the two images therefore creates a dichotomy between the "white" and the "indigenous" Australian, where the white is active, complex, and technologically advanced, and the Aboriginal is passive, primitive and simple. A final point is color: as a relic from the past, dark tones are still often carry negative connotations (Sturken $\&$ Cartwright 2009). Subsequently, the darkness of the image depicting the Aboriginal boy, and in particular when juxtaposed with the light image of the blonde girl, can potentially enforce a feeling of apprehension towards the foreign Other. 


\section{Conclusion}

The study concluded that there is a marked trend in the EFL textbooks analyzed to depict indigenous cultures as one-sided, and thus stereotypical, and to reducing otherwise complicated cultures to a few, superficial characteristics. It can also be argued that, overall, the images in the four textbook collections position the viewer to enter a closer social relationship with the white participants, than with the indigenous participants. The authority invested in schools and textbooks as disseminators of knowledge, and the heavy reliance on textbooks in the Norwegian ESL classroom (Charboneau 2012) compounds the effect of these images.

It has been argued that in order to increase greater interaction, understanding and respect between people with differing cultural backgrounds, as stated in the general aims for EFL education in Norway in the LK06 curriculum, it is important to encourage the attainment of intercultural competence. Furthermore, it has been argued that the values and attitudes held towards other cultures are an essential part of this. Indigenous peoples are by definition significantly different from the majority culture of the country they inhabit. Consequently, the representations of these cultures carry the additional risk of enforcing stereotypes and a sense of otherness. However, as maintained in the discussion, the images in the textbooks analyzed are not working effectively to show diversity or to bring down boundaries between "us" and "them", but are instead reinforcing these. Subsequently, there is not only a lost potential of increasing intercultural competence, but the images representing indigenous cultures in the textbooks are actively working against this. The answer to the main research question is therefore that the images in the four EFL textbooks analyzed in the current study to a large degree are potential carriers of myths and ideologies which directly contradict the general cultural aims of English language learning in Norway.

\subsection{Implications}

There are several implications that arise from these findings, both in relation to teaching practices in schools, as well as for textbook producers. It has been argued that images can be carriers of myths and ideologies, and that the school is an arena in which ideologies can most powerfully be instilled. The results from the current study show that the images in the four EFL textbooks to various degrees carry ideologies that contradict the general cultural aims of EFL education in Norway. It is therefore important that teachers are aware of the danger of visual stereotyping in relation to indigenous people, and consequently provide the pupils with many other images in addition to those that are found in the textbooks when these are fragmentary and lacking in diversity. As argued previously, images are not read in isolation, and the schools and teachers therefore have the opportunity to influence the way these images are interpreted. For example, discussing the images with pupils could encourage them to think about the way in which the images position them to view indigenous cultures. Through critically reading the visual representations, the ideologies and myths can be brought in to the open where they are less persuasive. Through this process, the pupils are enabled to take an active stance on whether they accept the positioning which is offered or not (Janks et al. 2014).

Certain implications can also be extracted from the results of this study for textbook producers, who have a choice when presenting images of people from different cultures. As argued by Janks et al. (2014), representational systems can both 
contribute to or challenge the ideologies and myths of a society. Subsequently, textbooks have the potential to show images of indigenous people which emphasize cultural diversity, rather than stereotypes, images which bring down dichotomies between 'us' and 'them', rather than enforcing them. Thus, the results from the study imply that the images that were analyzed not only contradict the general cultural aims, but that they represent a lost potential in relation to challenging naturalized myths and stereotypes.

\subsection{Limitations and recommendations for further research}

The current study applied a theoretical approach to the potential meanings of images. However, the actual meanings taken from the images by the viewers depend on a variety of factors, including among other things their personal background and the context in which the images are read.

While this study aimed to shed light on the potential meanings of images in textbooks, research is still needed on the actual interpretations made by pupils, on how textbook images are currently used in the classroom, and on how teachers should be trained in order to address these issues. 


\section{Works Cited}

Albers, P., Harste, J.C., Vander-Zanden, S. \& Felderman, C. (2008). Using popular culture to promote critical literacy practices. In Y. Kim, V. Risko, D. Comption, D. Dickinson, M. Hundles, R. Jimenez, K. Leander \& D. Rowe (Eds.), $57^{\text {th }}$ Yearbook of the National Reading Conference (pp. 70-83). Oak Cree, WI: NRC.

Althusser, L. (1971). Ideology and Ideological State Apparatuses. In L. Althusser (Ed.), Lenin and Philosophy and other Essays. New York: Monthly Review Press.

Arizpe, E. \& Styles, M. (2004). Seeing, Thinking and Knowing. In T. Grainger (Ed.), The Routledge Falmer Reader in Language and Literacy (pp. 185-198). London: Routledge.

Bamford, A. (2003). The Visual Literacy White Paper. Adobe Systems Pty Ltd., Australia. Online: http://www.adobe.co.uk/education/pdf/

Berger, J. (1972). Ways of Seeing. Harmondsworth: Penguin Books Limited.

Bøhn, H. \& Dypedahl, M. (2009). Interkulturell Kompetanse. In H. Bøhn \& M. Dypedahl, Veien til Interkulturell Kompetanse (pp. 151-158). Bergen: Fagbokforklaget.

Byram, M. (2012). Conceptualizing intercultural (communicative) competence and intercultural citizenship. In J. Jackson (Ed.), Routledge Handbook of Language and Intercultural Communication. London: Routledge.

Charboneau, R. 2012. Approaches and Practices Related to the Teaching of EFL Reading at the Norwegian Primary Level. In A. Hasslegreen, I. Drew and B. Sørheim (Eds.), The Young language Learner: Research-based Insights into Teaching and Learning (pp. 51-70). Bergen: Fagbokforlaget.

Cohn, N. (2013). The Visual Language of Comics. London: Bloomsbury.

Council of Europe (2001). CEFR (Common European Framework of Reference for Languages). Cambridge: Cambridge University Press.

Council of Europe (2008). White Paper on Intercultural Dialogue: Living Together as Equals in Dignity. Online: http://www.coe.int/t/dg4/intercultural/source/white\%20paper_final_revised_en.pdf

Dyer, R. (1997). The Matter of Whiteness. In R. Dyer, White: Essays on Race and Culture (pp. 1-40). Routledge.

Eisner, W. (2008). Comics and Sequential Art. New York: W.W. Norton \& Co. Freire, P. (1970). Pedagogy of the Oppressed. New York: Herder \& Herder.

Giroux, H. \& Penna, A. (1983). Social Education in the Classroom: The Dynamics of the Hidden Curriculum. In. H. Giroux \& David Purpel (Eds.), The Hidden Curriculum and Moral Education (100-121). Berkeley, California: McCutchan Publishing Corporation.

Giaschi, P. (2000). Gender Positioning in Education: A Critical Image Analysis of ESL texts. TESL Canada Journal, 18 (1), 32-46.

Giorgis, C., Johnson, N., Bonomo, A., Colbert, C. et al (1999). Visual literacy. Reading Teacher, 53 (2), 146-153.

Hall, S. (1997). Representation: Cultural Representations and Signifying Practices. London: SAGE Publications.

Hall, S. (2007). Encoding, Decoding. In S. During (Ed.) The Cultural Studies 
Reader (pp. 477-487). Routledge. (Original work published 1973)

Holliday, A. (2004). Intercultural Communication: An Advanced Resource Book.

Holliday, A., Hyde, M. \& Kullman, J. (2010). Intercultural Communication: An Advanced Resource Book (Second edition). London: Routledge.

Howells, R. and Negreiros, J. (2012). Visual Culture. London: Polity.

Jackson, P. (1968). Life in Classrooms. New York: Holt, Reinhart \& Winston.

Janks, H. (2010). Literacy and Power. London: Routledge.

Janks, H., Dixon, K., Ferreia, A., Granville, S. \& Newfield, D. (2014). Doing Critical Literacy. Texts and Activities for Students and Teachers. London: Routledge.

Jewitt, C. \& Oyama, R. (2001). Visual Meaning: a Social Semiotic Approach. In T. van Leeuwen \& C. Jewitt (Eds.), Handbook of Visual Analysis (pp. 134-156). London: SAGE Publications.

Kramsch, C. (1995). The Cultural Component of Language Teaching. Language, Culture and Curriculum, 8 (12), 83-92.

Kramsch, C. (2002). In Search of the Intercultural. (Review Article). Journal of Sociolinguistics 6 (2), 275-85.

Kress, G. \& van Leeuwen, T. (2006). Reading Images. The Grammar of Visual Design ( $2^{\text {nd }}$ Ed.). London: Routledge.

Lee, J. F. K. (2014). A Hidden Curriculum in Japanese EFL Textbooks: Gender Representation. Linguistics \& Education, 27, 39-53.

Lund, R. (2006). Questions of Culture and Context in English Language Textbooks. A Study of Textbooks for the Teaching of English in Norway (Doctoral thesis, Universitetet i Bergen). Bergen: Universitetet i Bergen.

Marefat, F. \& Marzban, S. (2014). Multimodal Analysis of Gender Representation in ELT Textbooks: Reader's Perceptions. Procedia - Social and Behavioural Sciences, 98, 1093-1099.

UDIR (2012). Framework for Basic Skills. Online:

http://www.udir.no/contentassets/fd2d6bfbf2364e1c98b73e030119bd38/framework_f or_basic_skills.pdf

UDIR (2013). English Subject Curriculum. Online: http://www.udir.no/kl06/eng103/Hele/?lplang=eng

UDIR (2015). Fremtidens skole. Fornyelse av fag og kompetanser. (NOU 2015:8).

Online:

https://www.regjeringen.no/contentassets/da148fec8c4a4ab88daa8b677a700292/no/pd fs/nou201520150008000dddpdfs.pdf

Sontag, S. (1977). On Photography. Harmondsworth: Penguin Books.

Sturken, M. \& Cartwright, L. (2009). Practices of Looking, an Introduction to Visual Culture (Second Edition). Oxford: Oxford University Press.

Taylor-Mendes, C. (2009). Construction of Racial Stereotypes in English as a Foreign Language (EFL) Textbooks. Images as Discourse. In Ryuko Kubota and Angel Lin (Eds.) Race, Culture and Identities in Second Language Education: Exploring Critically Engaged Practice. London: Routledge.

Vasquez, V., Tate, S. \& Harste, J. (2013). Negotiating Critical Literacies with Teachers: Theoretical Foundations and Pedagogical Resources for Pre-service and In-service Contexts. London: Routledge.

Winje, G. (2014). Elevers lesing av bilder i RLE. Norsk pedagogisk tidsskrift 5. 


\section{Nordic Journal of Modern Language Methodology}

Online: http://geirwinje.no/onewebmedia/elever-lese-bilder-rle.pdf

\section{EFL Textbooks}

Bromseth, B. H. \& Wigdahl, L. (2006). New Flight 1. Textbook. Oslo: Cappelen Damm.

Bromseth, B. H. \& Wigdahl, L. (2007). New Flight 2. Textbook. Oslo: Cappelen Damm.

Bromseth, B. H. \& Wigdahl, L. (2007). New Flight 3. Textbook. Oslo: Cappelen Damm.

Fenner, A.-B. N. \& Nordal-Pedersen, G. (2006). Searching 8. Learner's book. Engelsk for Ungdomstrinnet. Oslo: Gyldendal.

Fenner, A.-B. N. \& Nordal-Pedersen, G. (2008). Searching 9. Learner's book. Engelsk for Ungdomstrinnet. Oslo: Gyldendal.

Fenner, A.-B. N. \& Nordal-Pedersen, G. (2008). Searching 10. Learner's book. Engelsk for Ungdomstrinnet. Oslo: Gyldendal.

Heger, H. \& Wroldsen, N. (2006). Crossroads 8A. English for lower-secondary students. Bergen: Fagbokforlaget.

Heger, H. \& Wroldsen, N. (2007). Crossroads 9A. English for lower-secondary Students (learner's book). Bergen: Fagbokforlaget.

Heger, H. \& Wroldsen, N. (2008). Crossroads 10A. English for lower-secondary Students (learner's book). Bergen: Fagbokforlaget.

Larsen, F., Lia, H. B., Solberg, H. \& Westlake, P. (2006). Key English Textbook 8. Aschehoug.

Larsen, F., Lia, H. B., Solberg, H. \& Westlake, P. (2007). Key English Textbook 9. Aschehoug.

Larsen, F., Lia, H. B., Solberg, H. \& Westlake, P. (2008). Key English Textbook 10. Aschehoug. 